\title{
I Looked At Her As She Stooped
}

I looked at her as she stooped towards the smoking blaze. She was sixtynine and the steeplechase of her whole life had come to a halt.

"Well," I said. "I just thought I'd come over to see how you were getting along."

She turned and brandished the fire iron at me.

"Don't hit me with that," I said.

"I ought to."

"But you know how it is, Atlanta. I have been so busy I haven't had time."

"I ought to hit you with it."

"I wish you wouldn't."

"I ought to."

I approached her and took it away from her. Of course she raised her arm to strike. And there was a time when she could have made good her threat. She was much bigger than I. But her bones had knit. She had been robust and almost six foot, auburn haired. Now she was gaunt and haggard, white headed.

"How can you take away an old lady's cane?" she asked.

I put it in her hand and she sat down with it. She sat up straight with the fire iron gripped tightly and I couldn't take it. My heart came up in my throat.

"I'll see you tomorrow," I said, and I let myself out, crying.

\section{Without Warning Her Whole Body}

Without warning her whole body was swamped with a sense of utter misery, a sensation of sadness that she had never known before. And there was nothing she could do about it. She had lost her job and she would never find another and if she did she would lose that. She didn't want to work in the first place. She was only doing a favor to her stomach that seemed to think she ought to work for a living to support it.

She was tired of its constant belly aching. Her stomach was just lucky she wasn't Japanese, she would take a knife to it, that would shut it up for good.

She lay back and shut her ears to the growling. "Good for you to have hunger pangs once in awhile," she said. "We all have to suffer. Count your- 